\title{
An overview of land fund categories distribution in Surkhandarya, Uzbekistan
}

\author{
Khudoyberdi Abdivaitov ${ }^{1, *}$, Sanjarbek Muratov ${ }^{2}$, Abdurashid Altiyev ${ }^{1}$, Sevarakhon \\ Abdivaitova $^{3}$, Musurmon Norkulov ${ }^{4}$ and Barnokhon Khalilova ${ }^{1}$ \\ ${ }^{1}$ Tashkent Institute of Irrigation and Agricultural Mechanization Engineers (TIIAME), Land Use \\ Department, 39 Kari Niyazov Street, Uzbekistan \\ ${ }^{2}$ State Inspection of Geodesy Supervision under the State Committee on Land Resources, Geodesy, \\ Cartography and State Cadastre of the Republic of Uzbekistan, Osiyo Street \\ ${ }^{3}$ Tashkent Institute of Irrigation and Agricultural Mechanization Engineers (TIIAME), English \\ language Department, 39 Kari Niyazov Street, Uzbekistan \\ ${ }^{4}$ Uzbek State Scientific Research Institute of Land Management "Uzdavyerloyiha"
}

\begin{abstract}
Uzbekistan has a wide range of land use categories, because of its best geographical location. The distribution of the land fund according to its specific purpose is always one of the most important issues in the country. This article provides an analysis of the use of the Republican land fund for the last decade. Explanations of the concept of the land fund have been studied and detailed clarifications have been given for each of its categories. Surkhandarya region was selected as the main study area and the land fund of the last two years was analysed. During the work, statistical land-use data which provided from the state committee on land resources, geodesy, cartography and state cadastre of the Republic of Uzbekistan were used. Besides that, using the importance of geographic information system (GIS) and remote sensing techniques was reviewed for rational land use.
\end{abstract}

\section{Introduction}

The term land fund is used in all land legislation acts of Uzbekistan. An analysis of the literature reviewed during the study shows that the term has been explained by a number of scholars, including professor S.Avezbayev, who defined it as follows: The land fund is the total of all lands in a given area, within its boundaries (country, province, district, etc.), which for management, ownership, estate, use, and objects of rent [1]. Another scientist, K.Rakhmonov, gave a slightly different definition: Land fund - the part of the Earth's surface, in particular the bottom of water bodies, located within the state borders of the Republic of Uzbekistan, the administrative borders of the autonomous Republic of Karakalpakstan, regions, districts, cities [2].

The term of land fund is basically used by Commonwealth of Independent States and it is defined as total land area within the boundaries of individual land users or administrative divisions [3].

\footnotetext{
* Corresponding author: abdivaitov90@list.ru
} 
The issue of land distribution is a key part of economic development analysis. According to Hossein Azadi and others, the following objectives of land distribution are mentioned:

- to improve the living standards in rural areas

- to redistribute of land by improving new land registration

- to redistribute income through organising a new job

- to increase the productivity of agricultural products [4].

However, we think that a number of other points can be added, such as, through the proper distribution of land, it is possible to increase the efficiency of its use, to reduce the illegal occupation of land and etc.

The land fund of the Republic is regularly distributed and redistributed among all sectors of the economy for use in clearly defined purposes by categories. The distribution of the land fund should take into account the zoning of the land in terms of the natural adaptation of agriculture, the natural conditions of the area and a number of other important features. Therefore, the organization of rational and efficient use of land resources is always important and at the same time complex issue. The country's economy can be improved by addressing this issue as accurately as possible. At the same time, the process of rational distribution and redistribution of land resources of the Republic is not always carried out in accordance with the purpose, which shows that there are gaps in this regard. In addition, the lack of work done using Geographic information system (GIS) and remote sensing data requires to do research on this topic.

Land fund categories are a constant process of continually changing the size of the area. One of the reasons for this is that Uzbekistan has a high population growth rate compared to many other countries in Asia and the world. When land is allocated to the population for different purposes, it transfers from one category to another. Moreover, the population of this country has been significantly increased during the last decade, and the primary source of income of most of the people is directly connected to agriculture activities. Various factors such as geographical location, different climate conditions, soil fertility, timely exchange of seasons, proper road and power line networks, and water resources, provide this country to a potential of land use in a wide range of agriculture and industrial purposes. Today the importance of agriculture still plays one of the main role in the government's economy in Uzbekistan [5]. In comparison with the other four Central Asian countries, (i.e. Kazakhstan, Kyrgyzstan, Tajikistan, and Turkmenistan) agriculture has significantly developed in Uzbekistan at the beginning years of independence [6]. But the previous land use policy has caused a huge number of negative effects on the fertility of the soil in agricultural areas of Uzbekistan. In spite of a few land reforms that have been implemented until now, it can be easily defined the numerous issues in this field. Creating such a national data set and land categorisation make it possible to present a better land market system for the government and local people. Therefore, it is possible to increase the efficiency of land use only through the most accurate distribution and redistribution of the land fund of the republic among all sectors of the economy.

Observing changes in land categories is a body part of learning for the global environmental sciences research. The literature review provides the importance of remote sensing and GIS for numerous domains such as natural and social science [7]. Using remote sensing and GIS software is the best methods in order to know the spatial distribution and evolution of geographical phenomena related to land-use and land-cover changes [8]. Today, using various types of remote sensing data is the best option to evaluate, monitor and analyse other characteristics of land categories [9]. In addition, using the remote sensing data and analysis techniques can give a huge number of advantages such as for widely monitoring, detecting changes in time in land cover and land use [10]. Thus the 
significance of this study consists of a detailed analysis of the land fund and its categories at the country level.

\subsection{Overview of republican land fund categories distribution}

As of January 1 of each year, each department of land resources and state cadastre prepares a "Report on existing landowners, land users of irrigated agricultural land types and their distribution" and writes a comment letter for this report. The data in the report are obtained on the actual, territorial boundaries of arrays, subsidiary farms of organizations and institutions, other ministries, agricultural enterprises and other landowners, as well as land users, land categories and types. A report made a year in advance is used as a basis for a report for the current year. The analysis of data from the district and regional land resources and state cadastre organizations showed that data on 8 categories of land resources are not prepared at the district's level. Based on the information provided by all districts and regions, it is summarized by the state committee for geodesy and cadastre, and as a result, the Republican land fund is formed (Figure 1).

Each district prepares data about the changes in land resources and gives them to the region

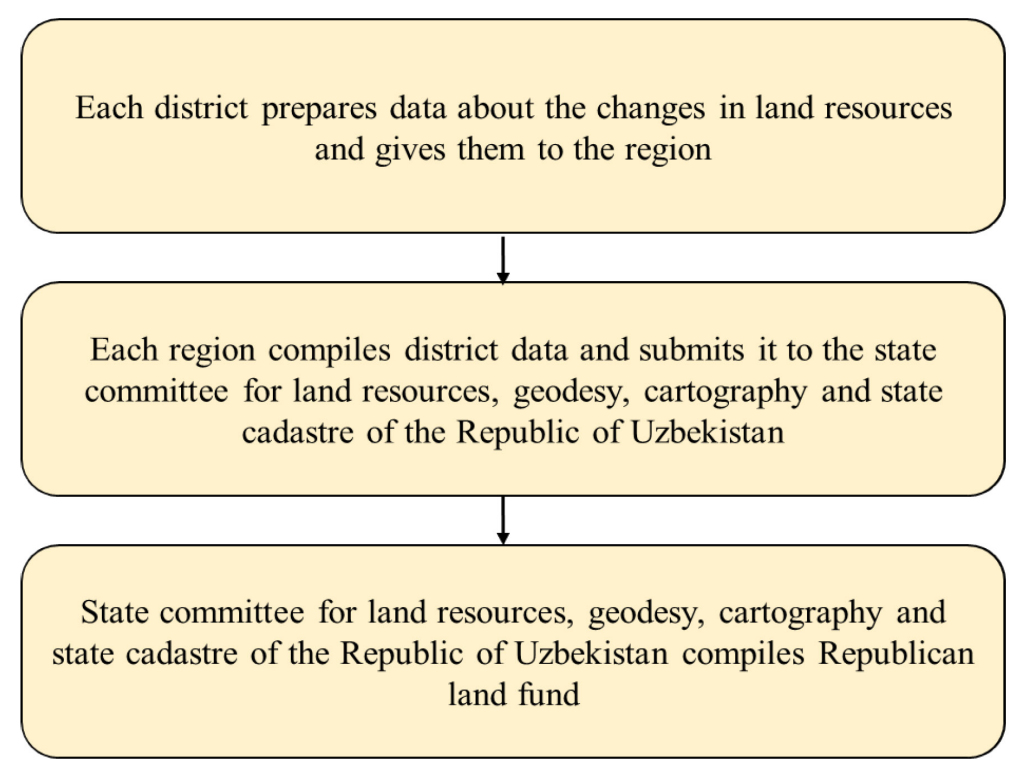

Fig. 1. Formation of Republican land fund (Note: There are 170 districts and 12 regions, 1 autonomous republic, capital city in Uzbekistan).

As of January 1 of each year, the state committee for land resources, geodesy, cartography and state cadastre of the Republic of Uzbekistan prepares a National Report on the state of land resources of the Republic. Because this Committee is a specially authorized state organization that implements the unified state policy in the field of land resources, geodesy, cartography and state cadastre. The report is compiled on the basis of information on all changes in the lands of enterprises, institutions, farms and organizations in the country and as a result of summarizing the annual land reports for the country, approved by the decisions of the district, city and regional governors. According to the National Report, the total land fund area is $448924 \mathrm{~km}^{2}$, in $2019.45 .08 \%$ of the total area i.e., $202633 \mathrm{~km}^{2}$ of land is used for agricultural purposes in the country (Table 1) [11]. Irrigated land is $43066 \mathrm{~km}^{2}$ or $9.6 \%$ of the total land area. 
Table 1. Distribution of the land fund of the Republic of Uzbekistan by categories, $\mathrm{km}^{2}$ (Analysis of changes for the period 2010-2019).

\begin{tabular}{|c|c|c|c|c|c|c|c|c|}
\hline \multirow[b]{2}{*}{ № } & \multirow[b]{2}{*}{$\begin{array}{l}\text { Categories of land } \\
\text { fund }\end{array}$} & \multirow{2}{*}{ 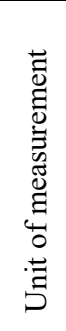 } & \multicolumn{2}{|c|}{2010 year } & \multicolumn{2}{|c|}{2019 year } & \multicolumn{2}{|c|}{$\begin{array}{l}\text { Difference } \\
2010-2019 \\
\text { years, (+/-) }\end{array}$} \\
\hline & & & 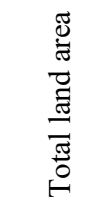 & 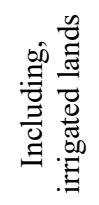 & 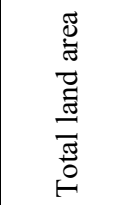 & 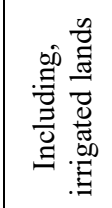 & 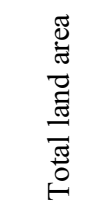 & 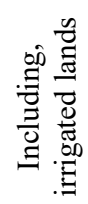 \\
\hline \multirow{2}{*}{1} & \multirow{2}{*}{ Agricultural lands } & $\mathrm{km}^{2}$ & 214532 & 42177 & 202363 & 41912 & -12169 & -265 \\
\hline & & $\%$ & 48.31 & 9.5 & 45.08 & 9.34 & -3.23 & -0.16 \\
\hline \multirow{2}{*}{2} & \multirow{2}{*}{$\begin{array}{l}\text { Lands of } \\
\text { settlements }\end{array}$} & $\mathrm{km}^{2}$ & 2204 & 483 & 2214 & 510 & 10 & 27 \\
\hline & & $\%$ & 0.50 & 0.1 & 0.49 & 0.11 & -0.01 & 0.01 \\
\hline \multirow{2}{*}{3} & \multirow{2}{*}{$\begin{array}{l}\text { Lands for industry, } \\
\text { transportation, } \\
\text { communications } \\
\text { defense and lands } \\
\text { for other purposes }\end{array}$} & $\mathrm{km}^{2}$ & 19958 & 120 & 8663 & 123 & -11295 & 3 \\
\hline & & $\%$ & 4.49 & 0.03 & 1.93 & 0.03 & -2.56 & 0 \\
\hline \multirow[b]{2}{*}{4} & \multirow{2}{*}{$\begin{array}{l}\text { Lands for nature } \\
\text { protection, } \\
\text { healthcare and } \\
\text { recreational } \\
\text { purposes }\end{array}$} & $\mathrm{km}^{2}$ & 759 & 6 & 7104 & 6 & 6345 & 0 \\
\hline & & $\%$ & 0.17 & 0.001 & 1.58 & 0.001 & 1.41 & 0 \\
\hline \multirow{2}{*}{5} & \multirow{2}{*}{$\begin{array}{l}\text { Lands for } \\
\text { historical and } \\
\text { cultural heritage }\end{array}$} & $\mathrm{km}^{2}$ & 11 & 0 & 145 & 0 & 134 & 0 \\
\hline & & $\%$ & 0.002 & 0 & 0.03 & 0 & 0.028 & 0 \\
\hline \multirow{2}{*}{6} & \multirow{2}{*}{$\begin{array}{l}\text { Lands of the forest } \\
\text { fund }\end{array}$} & $\mathrm{km}^{2}$ & 94623 & 307 & 111995 & 446 & 17372 & 139 \\
\hline & & $\%$ & 21.31 & 0.07 & 24.95 & 0.09 & 3.64 & 0.02 \\
\hline \multirow{2}{*}{7} & \multirow{2}{*}{$\begin{array}{l}\text { Lands of water } \\
\text { fund }\end{array}$} & $\mathrm{km}^{2}$ & 8211 & 46 & 8369 & 47 & 158 & 1 \\
\hline & & $\%$ & 1.85 & 0.01 & 1.87 & 0.01 & 0.02 & 0 \\
\hline \multirow{2}{*}{8} & \multirow{2}{*}{ Lands of reserve } & $\mathrm{km}^{2}$ & 103805 & 18 & 108071 & 22 & 4266 & 4 \\
\hline & & $\%$ & 23.37 & 0.004 & 24.07 & 0.005 & 0.7 & 0.001 \\
\hline & \multirow{2}{*}{ Total lands: } & $\mathrm{km}^{2}$ & 444103 & 43157 & \begin{tabular}{|l|l|}
48924 \\
\end{tabular} & 43066 & 4821 & -91 \\
\hline & & $\%$ & 100 & 9.72 & 100.0 & 9.59 & 0 & -0.13 \\
\hline
\end{tabular}

The land fund of the Republic of Uzbekistan has its own characteristics in accordance with the purpose and procedure of land use, which are divided into 8 categories in accordance with article 8 of the Land Code of the Republic of Uzbekistan. The distribution of the land fund by categories as of January 1, 2019 is shown in table 1 above [12]. The table shows that from 2019 to 2010 , changes can be seen in all categories of the country's land fund. The following is a description of the republican land fund by categories and changes in their areas (Table 1).

Changes in the Republican land fund for 2010-2019 are discussed for each category. These data show that the distribution of land resources and their categories varies from region to region, with the share of agriculture, forestry and water resources, as well as reserve land being high. 
The first category of land fund includes lands allocated to agricultural enterprises and organizations, institutions and citizens engaged in the cultivation of agricultural products or for this purpose [13]. There is a significant decrease in the amount of this category of land, i.e. by $12169 \mathrm{~km}^{2}$ compared to the total area of the land fund of the republic, and irrigated land by $265 \mathrm{~km}^{2}$.

The second category of land fund includes rural settlements located within the administrative boundaries of cities and towns and not included in the lands used by agricultural, forestry enterprises, institutions and organizations. Relative growth can be observed in the land area of settlements.

The third category of lands of the land fund includes railway, inland water transport, automobile, air and pipeline transport, which are given to industrial enterprises, including mining, energy enterprises for permanent use for production and construction of ancillary buildings and structures; communications, radio, television and information, military units of the armed forces, border, Internal Affairs and railways, military educational institutions, enterprises, institutions and organizations, land for defence purposes and other purposes for the location of communication lines and related facilities lands given to legal entities for use. The area of land used for industry, transport, communications, defence and other purposes decreased by $11295 \mathrm{~km}^{2}$ compared to the total area of the land fund of the republic.

The fourth category of land resources includes lands occupied by specially protected natural areas, which have natural healing properties, as well as lands used for public recreation and tourism. The main part of this category of land is occupied by nature reserves and national parks. State nature reserves are nature protection, research and environmental education institutions whose purpose is to preserve and study natural processes and events, the genetic fund of flora and fauna, certain groups of plants and animals, and typical and unique ecosystems. Between 2019 and 2010, the area of the land fund increased by $6345 \mathrm{~km}^{2}$.

The fifth category of lands of the land fund includes historical and cultural reserves, memorial gardens, cemeteries, archaeological, historical and cultural monuments, lands given to the relevant institutions and organizations for permanent use and are specially protected. This category of land increased by $134 \mathrm{~km}^{2}$.

The sixth category of land resources includes lands covered with forests, as well as lands allocated for forestry needs, even if they are not covered by forests. Considering the nature protection features of forest areas and the long process of reforestation, it is necessary to pay more attention to the problem of their protection and reproduction. For this reason, since 1991, forested pastures and hayfields used by agricultural enterprises and organizations have been transferred to the category of forest lands in accordance with the established procedure. This creates some favourable conditions for expanding the area of forest lands and, on this basis, for preventing soil degradation and deforestation for economic purposes. Among the categories of land, the largest increase in land area is for these purposes, an increase of $17372 \mathrm{~km}^{2}$.

Lands of the seventh category of the land fund are allocated to enterprises, institutions and organizations for water management needs in the region occupied by water basins, rivers, lakes, reservoirs, hydraulic and other water management structures, as well as along the banks of water basins and other water bodies lands. Lands of the water fund include lands occupied by water bodies, structures, and lands of protection zones adjacent to water bodies allocated for water management needs. Lands of this category increased by $158 \mathrm{~km}^{2}$.

The last eighth category of the land fund includes all (including underwater) reserve lands that have not been transferred to legal entities and individuals for the purpose of possession, use and rent of lands and are not included in other land categories. The difference is $4266 \mathrm{~km}^{2}$. 


\section{Materials and methods}

\subsection{Study area}

Surkhandarya is located in the extreme south-east part of Uzbekistan, between $37^{\circ} 00^{\prime}$ and $39^{\circ} 20^{\prime}$ north and $66^{\circ} 30^{\prime}$ and $68^{\circ} 20^{\prime}$ east, and is bounded on the north by the Hissor ridge, on the east by the Babatag ridge, on the northwest by the Boysun ridge, and on the west by the Kuhitang ridge. The region is divided into 14 districts. As of January 1, 2020, according data to the regional department of land resources and state cadastre, the land area of the districts is distributed as follows (Fig. 2). The Surkhandarya region is the hottest and longest growing region in the country due to the fact that it is surrounded by high mountains from the north, where cold air masses come from. In the relief of Surkhandarya, along with the mountains, there are also plains. The southern slopes of the Hissor ridge, which surround the northern part of the region, face the Surkhandarya. Its highest peak is $4643 \mathrm{~m}$ above sea level. The surface of the region gradually decreases from north to south. There are lowlands in the area, between which there are narrow and deep valleys. As Surkhandarya differs from other regions by its relief, climate, natural conditions, soils and many other features, it is very important to properly organize the land use system.

\subsection{Tests}

During this part, we used different programs such as ArcGIS, ENVI image analysis software were used for visualising the topographic map of the study area (Fig. 3) and doing Land use and Land Cover (LULC) map (Fig. 5). Another software Global Mapper is also widely used in the worldwide geospatial community by a huge number of researchers for the last three decades [14]. Because today remote sensing techniques are the most famous methods for LULC change detection. For different aspects of land cover change, multitemporal remote sensing (RS) based on change detection analysis is used [15-16].

For a better representation of the topographic map of Surkhandarya region, we used TIN (triangulated irregular network) tool. The tin file was created and visualised in figure 3. Data were downloaded on the website of USGS (United States Geological Survey) Earth Explorer. Then mosaic tool was used in ArcGIS and as a result made the topographic map of the study area.

For LULC map, Landsat 8 OLI (operational land imager) data of July 2018 were also downloaded on the website of USGS. The Optical Landsat 8 OLI used in this part is Level $1 \mathrm{C}$ ortho-rectified imagery data. Besides that, radiometric calibration was performed to accurately represent and convert the satellite digital number data (DN) values to radiance with help ENVI 5.0 software. The atmospheric correction was applied in order to remove or reduce the influence of the atmosphere. For all the processing and post-classification steps were done using the software packages ENVI 5.0 and ArcGIS 10.6.1. Supervised classification methods and maximum likelihood algorithm were used for making LULC maps. Because at the present time maximum likelihood algorithms are prominent and were repeatedly used effectively in assessing satellite imageries [17].

In addition, ArcGIS was used for doing the map of the territorial administrative division of Surkhandarya region and the diagram of distribution of land areas in the districts was done using Microsoft Excel 2019. 

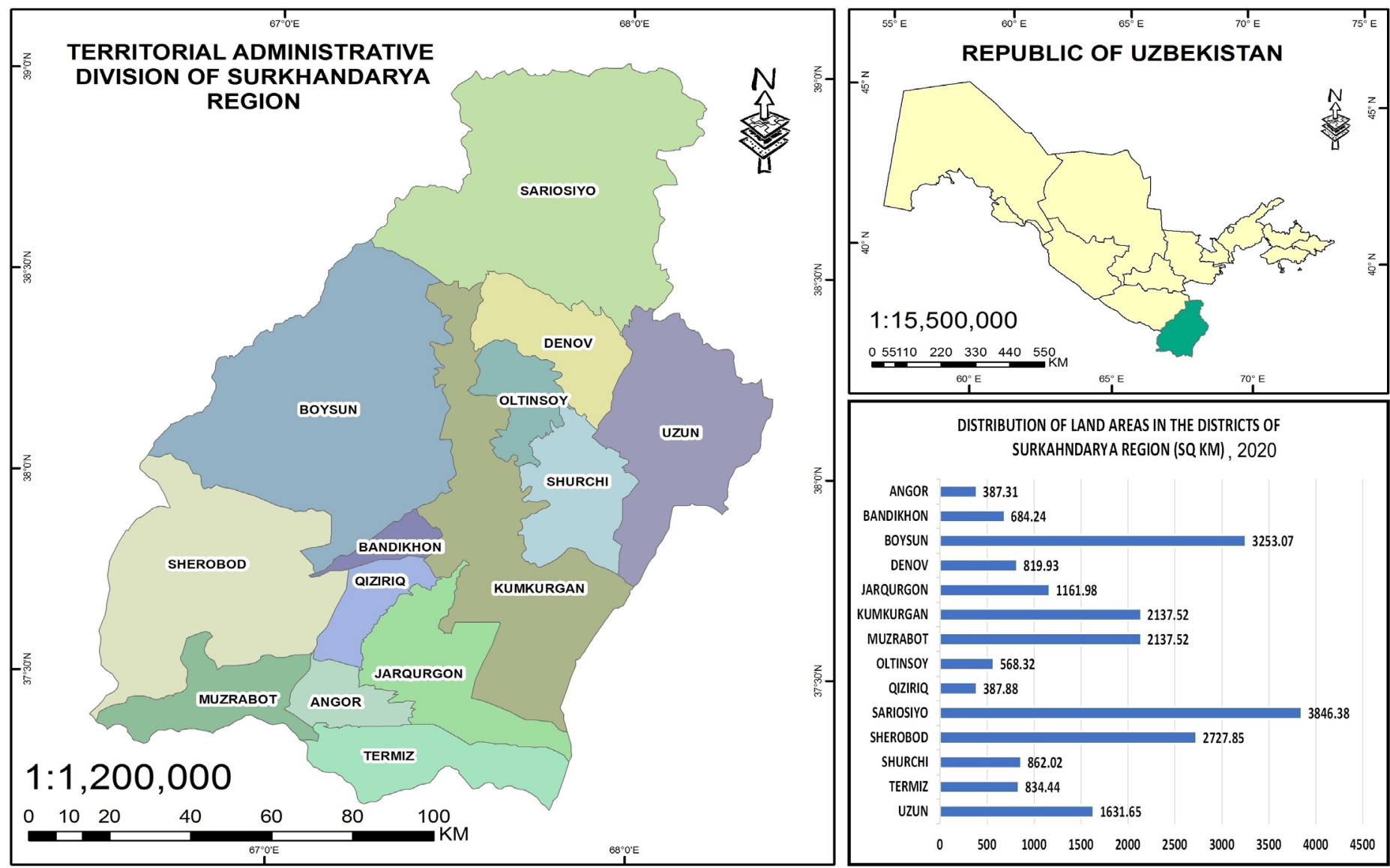

Fig. 2. Location of the study area. 


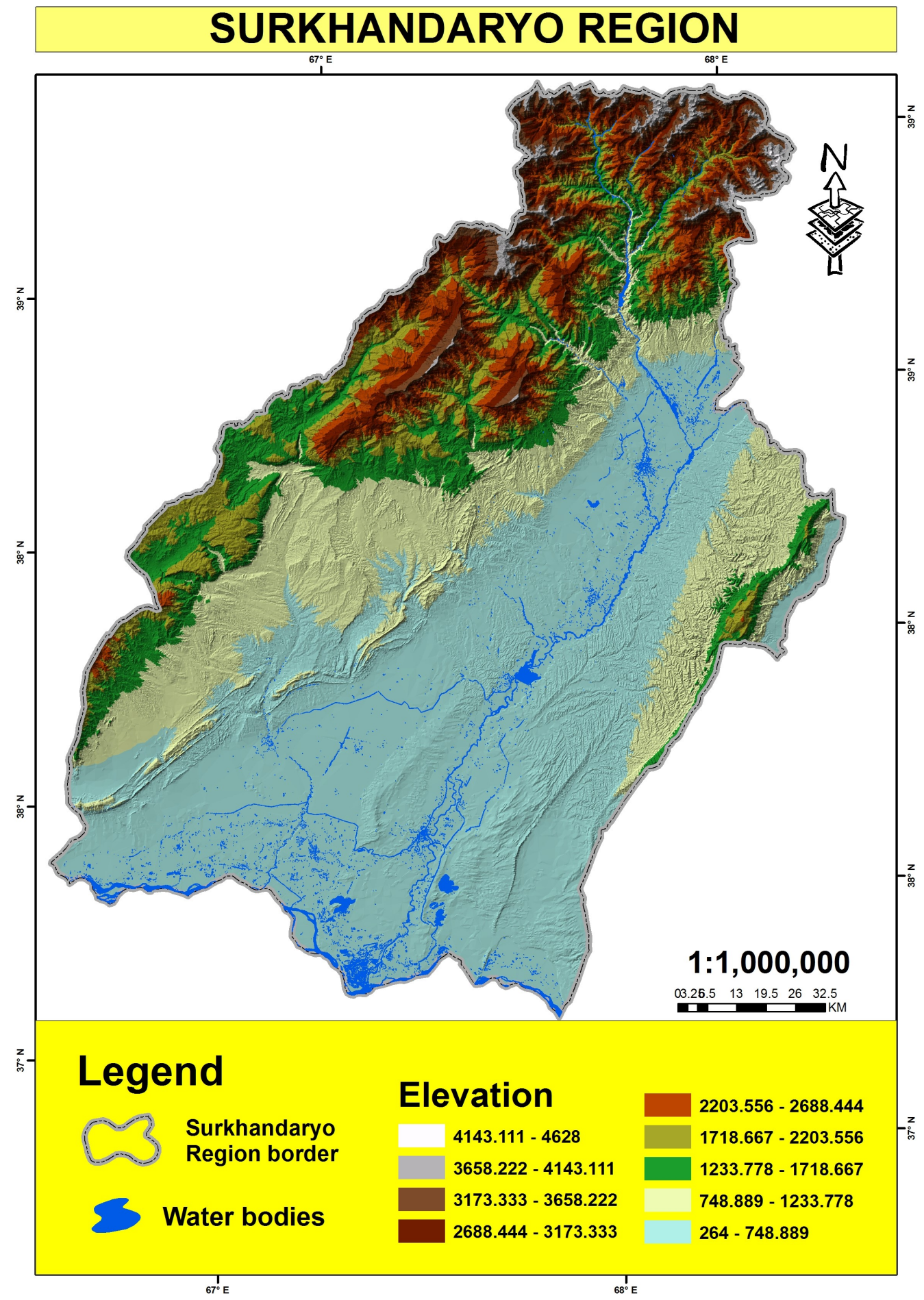

Fig. 3. The topographic map of Surkhandarya Region. 


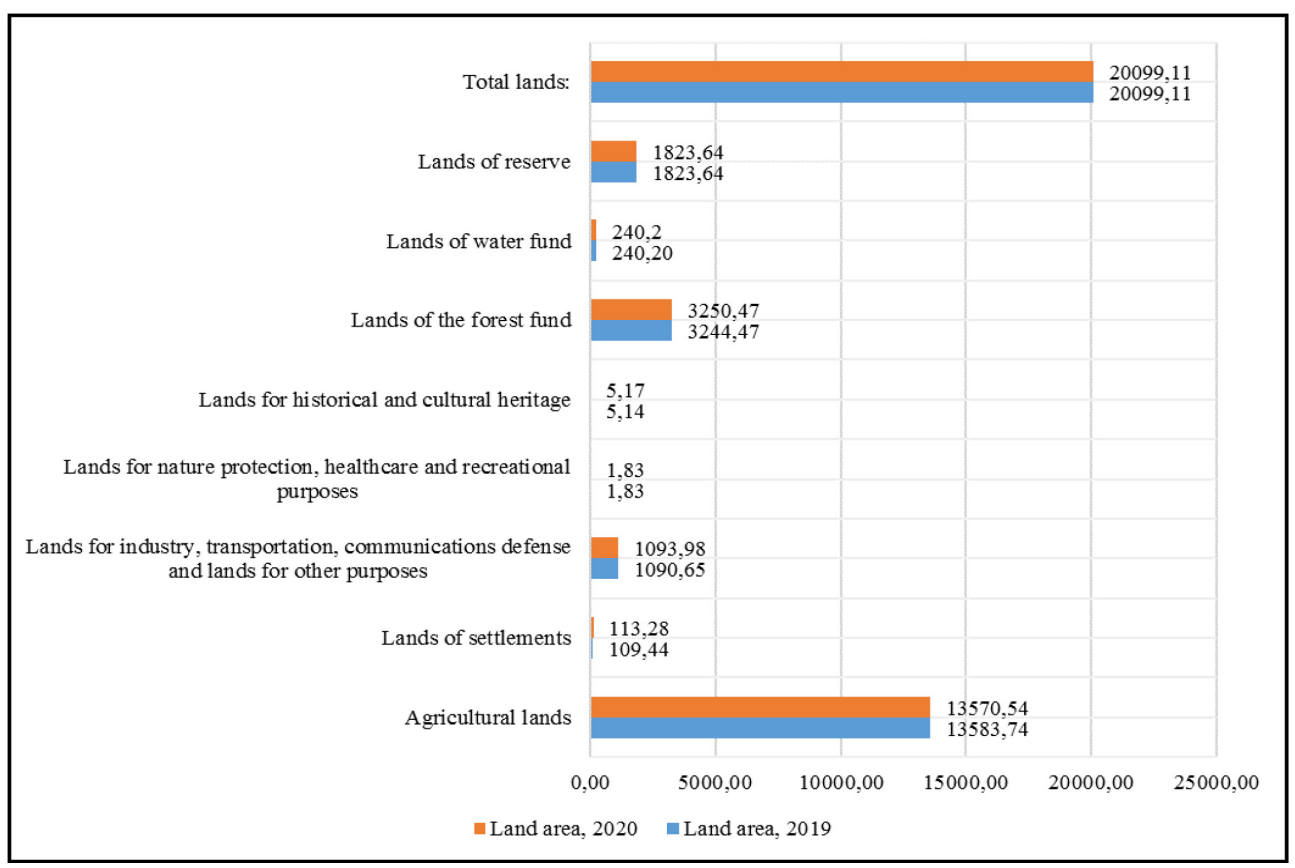

Fig. 4. Distribution of land fund of Surkhandarya region by categories $\left(\mathrm{km}^{2}\right)$.

If we analyze the changes of the land fund of the region in the last two years (20192020), we can observe a slight change in each category, except lands for nature protection, healthcare and recreational purposes. The main part of the land fund of Surkhandarya region is agricultural land (67.6\% of the total land area of the region). Lands for industry, transportation, communications defence and lands for other purposes has slightly increased, namely $3.33 \mathrm{~km}^{2}$ (Fig. 4).

\section{Results and discussions}

The classification of the land fund in the Republic of Uzbekistan does not differ much from the categories listed in Article 7 of the Land Code of the Russian Federation. That is, the fourth and fifth categories of land fund are recognized as one category in the Land Code of the Russian Federation [18]. It is called as lands of specially protected territories and objects. Other land fund categories called the same names. Therefore, the land fund is divided into eight categories in Uzbekistan, it is seven categories in the Russian Federation. It is possible to see how much the land fund needs to be properly distributed and redistributed in all sectors of the economy. Therefore, the main problem of the world land fund is to regulate the use of agricultural land. In many countries, measures are being taken to preserve the land fund and regulate its composition [19].

Correctly land distribution among in every single land users and carrying out constantly land monitoring require the best solution. In generally land resources are considered to be the important resource of the economy. That's why organizing rational and effective land use is one of the top problems in Uzbekistan now. One of the important measures of organizing rational land use is land management. The conception of land management is understood about land policy, land laws, land monitoring, state regulation, and economic development [20]. Using modern technics and technologies in doing land management work is today's demand. Soil salinity could be clearly explained in the maps by using 
modern GIS technologies [21]. However, it is difficult to find GIS and remote sensing works when categorizing lands for the study area. One of the main reasons for this is that the speed and quality of internet connection is not good [22]. Internet connectivity is often a problem in this country for downloading remote sensing data. This should be taken into account when working GIS applications and materials (e.g. ArcGIS Pro, ArcGIS Online, downloading free satellite imagery data sources such as USGS (United States Geological Survey) Earth Explorer, Landsat and etc.).

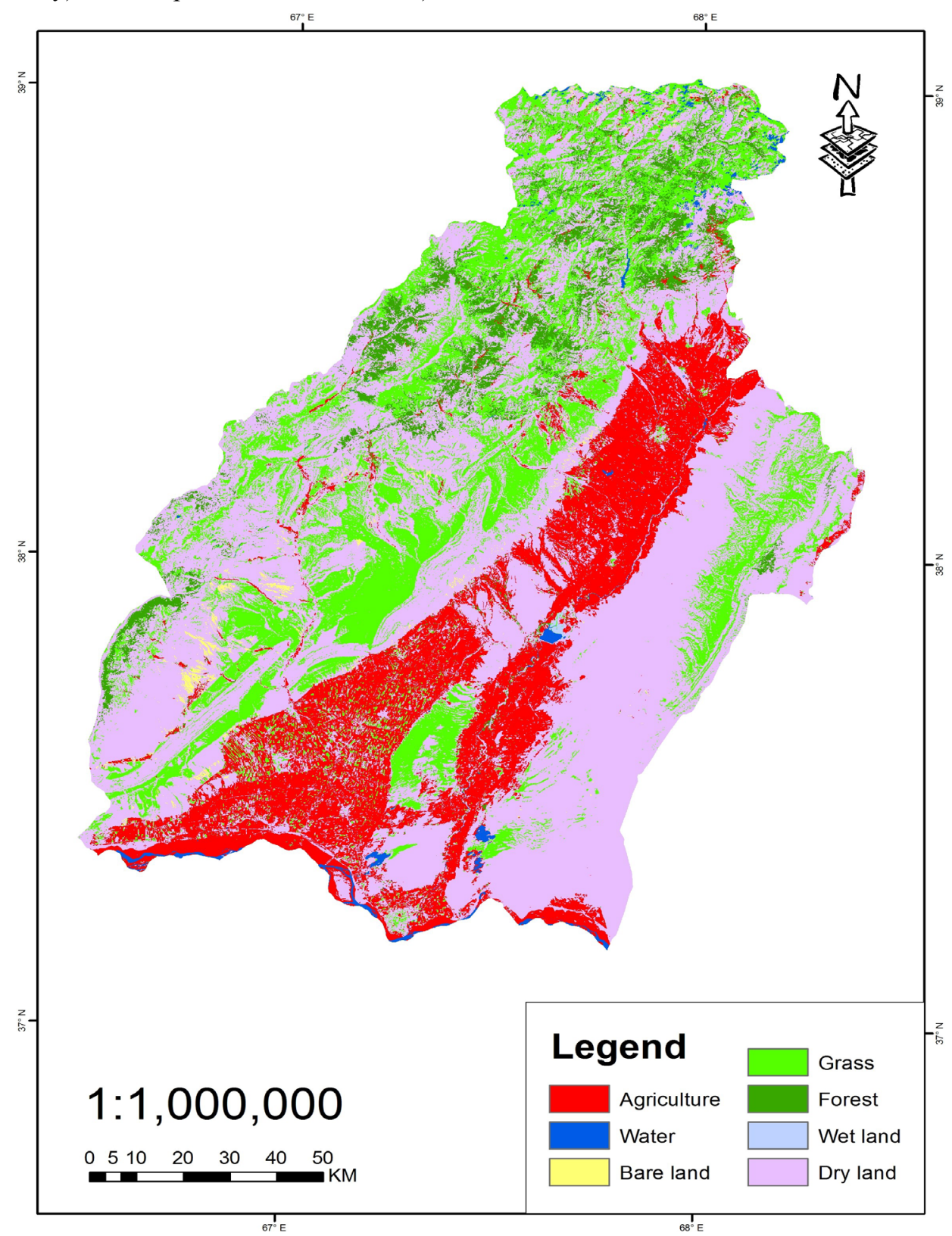

Fig. 5. Land use and land cover (LULC) map of Surkhandarya region derived from Landsat 8 OLI (operational land imager). 
LULC map shows that this region has different types of LULC classes, such as agricultural lands, forest, water, grass, wetland and dry land. In general, Surkhandarya region is surrounded by mountains on three sides. It mains that this region of Uzbekistan has a huge potential on using these types of land categories, especially for the cultivation of agricultural products, expansion of forest areas, further development of cattle - raising in pasture areas and etc. Equations should be centred and should be numbered with the number on the right-hand side.

\section{Conclusion}

In this paper, the distribution of land fund categories in Uzbekistan have been reviewed. The use of land resources was analyzed on the example of Surkhandarya region and at the national level. Some papers were reviewed on how the importance of remote sensing and GIS for land use. The government lands of Uzbekistan still have not been evaluated by the earth observation data of Sentinel-1 \& 2 for land use suitability purpose. There is a need to analyse the usefulness of these lands using the current applications of geographic information system and earth observation data. More work is required to organize of extensive use of modern GIS and remote sensing data in the assessment, observation and analysis of a number of land features in Uzbekistan. Any sustainable development in all fields should balance preparing high qualified experts, the most modern information supply, and good policy in the country.

We would like to thank Josef Strobl and Sabine Hennig from Department of Geoinformatics Z_GIS, University of Salzburg, Austria for their suggestions during this paper.

\section{References}

1. S. Avezbayev, S.Voklov, Land management projecting. Textbook, Tashkent: Yangi asr avlodi, p. 784, (2002)

2. Q. Rakhmonov, Sh. Narbayev, Z. Muqumov, Land resource management. Textbook, TIIAME, p. 157, (2018)

3. S.Voklov. Basics of land management. Textbooks and manuals for students of higher educational institutions. Moscow : P. 53-59. (2015)

4. H. Azadi, E. Vanhaute, K. Janečková, P. Sklenička, D. Teklemariam, L. Feng, F. Witlox, Evolution of land distribution in the context of development theories, Land Use Policy, P. 1-9, 97 (2020). https://doi.org/10.1016/j.landusepol.2020.104730

5. I. Abdullaev, M. Giordano, A. Rasulov, "Cotton in Uzbekistan: water and welfare", The cotton sector in Central Asia economic policy and development challenges. The School of Oriental and African Studies. University of London, London: P. 112-128, (2007)

6. P. Bloch, "Agrarian reform in Uzbekistan and other Central Asian countries", Land Tenure Center University of Wisconsin-Madison, WORKING PAPER, NO. 49, May (2002)

7. S. Hennig, A. Nazarkulova, Benefits and Challenges of eLearning in Central Asia. International Journal of Geoinformatics, P. 43-51, 15, (2019)

8. E. Popovici, K. Gheorghe, Assessment of changes in land-use and land-cover pattern in Romania using CORINE Land Cover database. Carpathian Journal of Earth and Environmental Sciences, 8, P. 195-208, (2013) 
9. S. Fonji, and G. Taff, "Using satellite data to monitor land-use land-cover change in North-eastern Latvia" Springerplus 3(1): 61. (2014)

10. J. Rogan, and D. Chen, "Remote sensing technology for mapping and monitoring landcover and land-use change" Progress in planning 61(4): P.301-325. (2004).

11. National Report on the State of Land Resources of the Republic of Uzbekistan, (20102019). State committee for land resources, geodesy, cartography and state cadastre of the Republic of Uzbekistan. https://ygk.uz/

12. Land Code of the Republic of Uzbekistan. Tashkent, Adolat, (2018). https://ygk.uz/uz/node/705

13. Land fund of the Republic of Uzbekistan, (2010-2019). State committee for land resources, geodesy, cartography and state cadastre of the Republic of Uzbekistan. https://ygk.uz/

14. H. Mohd, and Ch. Ruzinoor, Online 3D terrain visualisation using Unity 3D game engine: A comparison of different contour intervals terrain data draped with UAV images, IOP Conference Series: Earth and Environmental Science, 37, (2016)

15. X. Li, S. Zhao, H. Yang, D. Cong, Z. Zhang. A Bi-Band Binary Mask Based LandUse Change Detection Using Landsat 8 OLI Imagery. Sustainability, 9 (3), p.479, (2017).

16. O. R. Abd El-Kawy, J. K. Rød, H. A. Ismail, A. S. Suliman. Land use and land cover change detection in the western Nile delta of Egypt using remote sensing data. Applied Geography, 31 (2), p.483, (2011).

17. A. C. Abino, S.Y. Kim, M. N. Jang, Y. J. Lee, J. S. Chung. Assessing land use and land cover of the Marikina sub-watershed, Philippines. Forest Science and Technology, 11 (2), p.65, (2015).

18. Land Code of the Russian Federation of October 25, (2001). https://cislegislation.com/document.fwx?rgn=3104

19. A. Altiyev. Development of mechanisms of regulating the system of using land resources, Doctoral dissertation, (2019)

20. S. Enemark, Building land information policies. Proceedings of Special Forum on Building Land Information Policies in the Americas. Aguascalientes, Mexico, Citeseer, (2004)

21. T. Gorji, A. Tanik, E. Sertel "Soil salinity prediction, monitoring and mapping using modern technologies" Procedia Earth and Planetary Science 15: P. 507-512, (2015)

22. O. Akbarov, B. Markus, and A.Podor, Development of Advanced Education in Geoinformatics for Enabling Sustainable Development in Uzbekistan. Proceedings FIG Congress, P. 1-15, (2014) 